\title{
A histological study of the eye lesions in 12 leprosy patients with tuberculoid lesion in 4 eyes
}

\author{
F. BRANDT, ${ }^{*} \|$ Z. R. SHI, $\dagger$ H. M. ZHOU, $\ddagger$ B. LU, $\S$ \\ H. WU \& N. RAIT \\ *Ludwigstr.97, 8265 Neuoetting, Germany; $\dagger$ Department of \\ Ophthalmology, Quindao Medical College, China; $\ddagger$ Department of \\ Pathology, Quindao Medical College, China; §China Leprosy \\ Centre, Quindao, China; and $\uparrow$ Kathmandu Lens Clinic, Kathmandu, \\ Nepal
}

\section{Accepted for publication 9 October 1992}

\begin{abstract}
Summary The histological reactions in 12 eyes of 12 leprosy patients were studied (5 BT, 1 BB, 1 BL and 5 LL). Granuloma lesions composed of epithelioid cells, Langerhans giant cells, macrophages and lymphocytes were found in various intraocular tissues, e.g. cornea, sclera, iris, ciliary body or retina in 4 patients (1 BT and $3 \mathrm{LL}$ ). Of the $3 \mathrm{LL}$ patients, according to the records, 2 were cured and in the other patient the outcome of the treatment was not mentioned. In view of the finding of the granulomatous lesions in the clinically cured patients and tuberculoid granuloma in the intraocular tissues in the LL patients, could there be some peculiarities in the intraocular sites? Or perhaps the tuberculoid reaction is just a manifestation of an upgrading reaction? More examinations on human leprosy eye specimens will be needed to answer these questions.
\end{abstract}

\section{Introduction}

Leprosy patients frequently suffer eye damage-about a million leprosy patients are blind. ${ }^{1}$ The lesions of the eyes are either caused directly by the Mycobacterium leprae or its derivatives, or indirectly by the dysfunction of the sensory and motor nerves as a result of the disease. These lesions may finally lead to corneal opacity, changing of the intraocular pressure, cataract and then blindness.

The clinical aspects of the effects of leprosy on the human eye have often been described in detail, ${ }^{3}$ but the pathohistological aspect of this has only rarely been documented and the cases investigated have been limited, ${ }^{2,4,5,7-9}$ probably because it is hard to get eye specimens.

Over a period of many years we gathered eye specimens from 12 leprosy patients. Their pathological histology was studied and the results are presented.

\| Correspondence. 
Table 1. The clinical aspect of the patients studied

\begin{tabular}{|c|c|c|c|c|c|c|}
\hline $\begin{array}{l}\text { Patient } \\
\text { No. }\end{array}$ & Sex & Age & Type & $\begin{array}{l}\text { Duration } \\
\text { (year) }\end{array}$ & $\begin{array}{l}\text { Therapy and } \\
\text { outcome }\end{array}$ & Clinical manifestations \\
\hline 1 & f & 40 & BT & 14 & $7 \mathrm{yr}, \mathrm{DDS}$ & Left eye, no lagophthalmos, phthiasis bulbi, blind \\
\hline 2 & $\mathrm{~m}$ & 70 & $\mathrm{BL}$ & 32 & $25 \mathrm{yr}$ & $\begin{array}{l}\text { Right eye, lagophthalmos III, opacity and } \\
\text { vascularization of cornea, blind }\end{array}$ \\
\hline 3 & $\mathrm{~m}$ & 40 & BT & $30+$ & $12 \mathrm{yr}, \mathrm{DDS}$ & Left eye, no lagophthalmos, blind \\
\hline 4 & $\mathrm{~m}$ & 56 & BT & 36 & $20 \mathrm{yr}, \mathrm{DDS}$ & $*$ \\
\hline 5 & $\mathrm{~m}$ & 28 & BT & $*$ & * & $\begin{array}{l}\text { Right eye, corneal ulcer and perforation, } \\
\text { panophthalmitis }\end{array}$ \\
\hline 6 & $\mathrm{~m}$ & 42 & LL & * & * & $\begin{array}{l}\text { Right eye, pain and blind for } 10 \text { years, atrophy of the } \\
\text { eyeball }\end{array}$ \\
\hline 7 & $\mathrm{~m}$ & 48 & LL & * & * & Right eye, blind and atrophy for 10 years \\
\hline 8 & $\mathrm{~m}$ & 50 & BT & 24 & $12 \mathrm{yr}, \mathrm{DDS}$ & Right eye, lagophthalmos III, blind \\
\hline 9 & $\mathrm{~m}$ & 45 & BB & $40 \pm$ & $35 \mathrm{yr}, \mathrm{DDS}$ & Left eye, lagophthalmos II, blind and atrophy \\
\hline 10 & f & 71 & LL & 45 & cured & $\begin{array}{l}\text { Right eye, lagophthalmos for } 20 \text { years, frequent } \\
\text { redness, pain, sight lost for } 6 \text { years, eyeball atrophic }\end{array}$ \\
\hline 11 & $\mathrm{~m}$ & 64 & LL & 45 & cured & $\begin{array}{l}\text { Right eye, lagophthalmos for } 20 \text { years, frequent } \\
\text { redness, pain, lacrimation, photophobia, and eyeball } \\
\text { atrophic }\end{array}$ \\
\hline 12 & $\mathrm{f}$ & 65 & LL & 32 & cured & $\begin{array}{l}\text { Right eye, frequent redness, pain, lacrimation, } \\
\text { photophobia, sight loss for } 30 \text { years; lagophthalmos } \\
\text { for } 20+\text { years; corneal leucoma for } 10+\text { years; } \\
\text { eyeball atrophic }\end{array}$ \\
\hline
\end{tabular}

* Not known.

\section{Materials and methods}

We obtained eyes from 12 leprosy patients from leprosy clinics in China and Nepal, after enucleation. The operations were performed to stop pain in sightless eyes. The main clinical points of these patients are shown in Table 1.

The eyes were fixed in 10\% formalin, dehydrated with graded alcohol and embedded in celloidin or paraffin. The sections were stained with H\&E. Some of the sections were stained by the Fite-Faraco method.

\section{Results}

Atrophy of ocular tissues in various degrees was observed in all 12 eyes.

\section{CORNEA}

Focal or diffuse, mild or moderate infiltrations of lymphocytes, plasma cells, and some macrophages and neutrophils, as well as scar tissues were observed in the stroma of the cornea in all 12 cases. In 7 cases (Patients 1, 2, 3, 4, 8, 10 and 11) scar tissue was present in the whole thickness of the stroma with adhesion of the iris (corneal perforation and adhesive corneal leucoma) and there was focal thinning of the cornea in some of the cases. In 2 cases (Patients 5 and 12) small nodules composed of some epithelioid cells, 


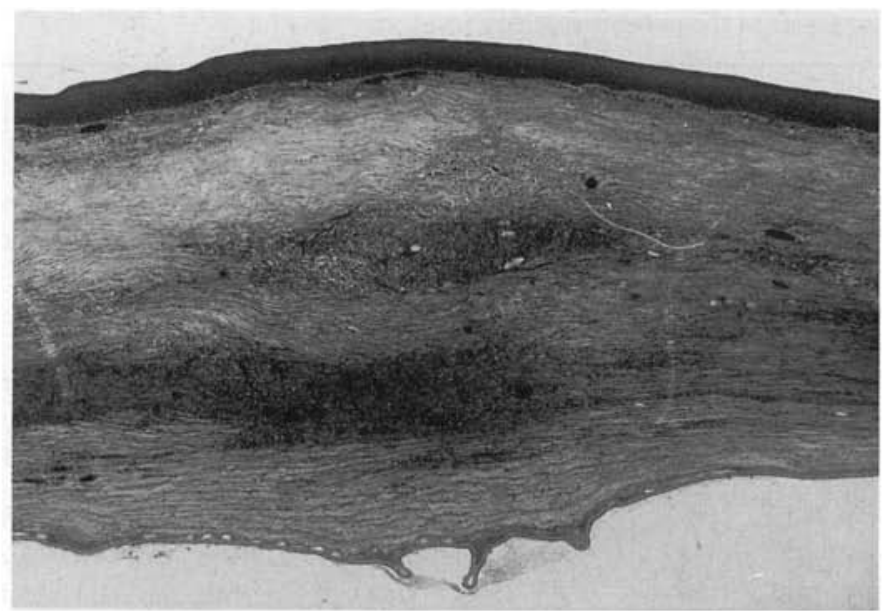

Figure 1. Granulomatous lesions in the stroma of the cornea (Patient 12) H\&E $\times 100$.

macrophages and Langerhans giant cells were seen (Figures 1 and 2) a mong the chronic inflammatory cell infiltrations.

SCLERA

Nonspecific chronic inflammatory cell infiltration in the anterior part of the sclera was the predominant lesion seen. In Patient 12 this cell infiltration was more significant around the nerves traversing the sclera. In Patient 6 epithelioid cells with Langerhans giant cells, mixed with some macrophages and lymphocytes, were gathered around nerves traversing the sclera. In some places thickening of the neurilemma was noted. In another eye (Patient

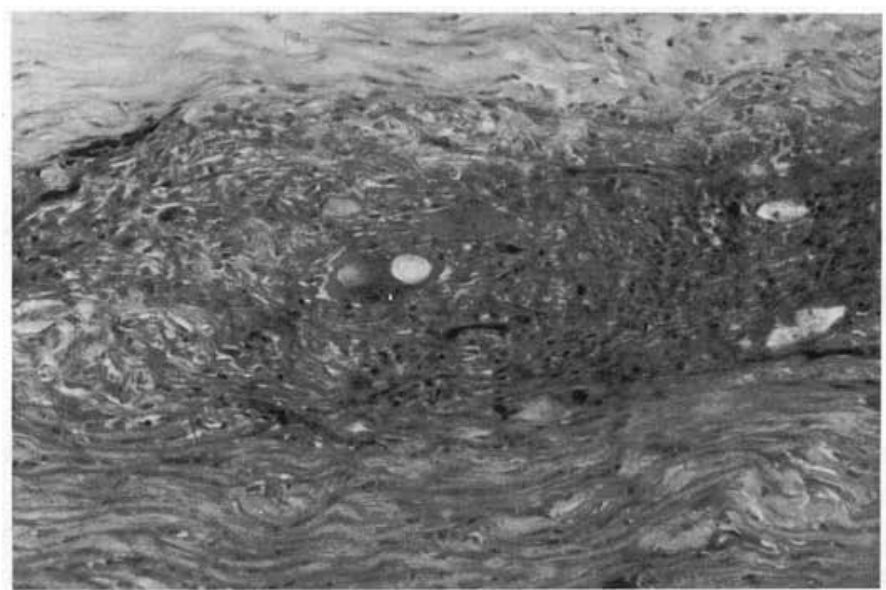

Figure 2. A higher view of the granulomatous reaction in the stroma of the cornea, showing Langerhans giant cells, epithelioid cells, lymphocytes (Patient 12). H\&E $\times 400$. 


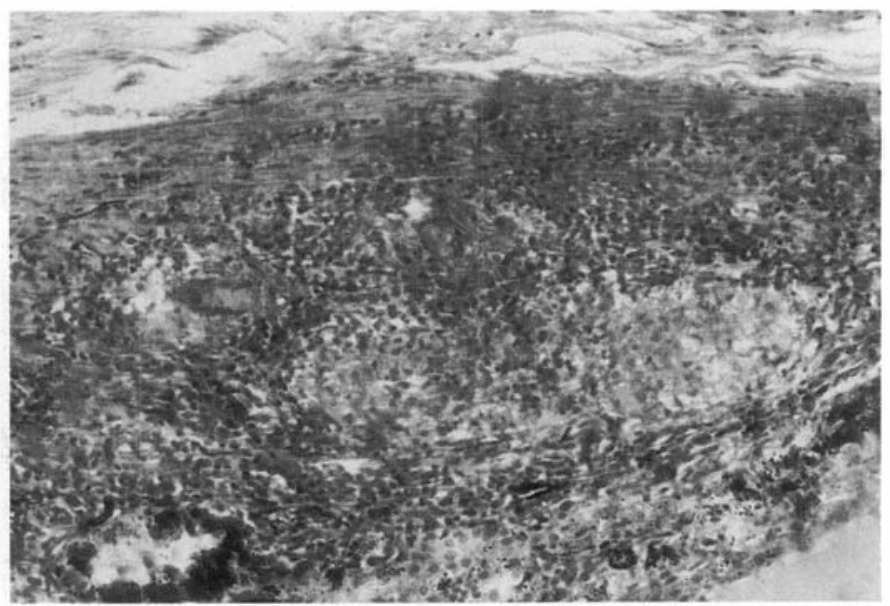

Figure 3. Granulomas in the ciliary body, showing the tuberculoid structure and many lymphocytes (Patient 6). $\mathrm{H} \& \mathrm{E} \times 400$.

2), a cyst, with pigment epithelia lining, was formed at the anterior part of the sclera and local thinning and ectasia was seen in the pre-equatorial region.

\section{IRIS AND CILIARY BODY}

Atrophy in various degrees occurred in 11 of the 12 specimens. Focal infiltrations of inflammatory cells were also found in 11 eyes. In 3 eyes small nodules composed of epithelioid cells, macrophages and Langerhans giant cells were seen among the other small round cells ((Patient 6 in the iris and in the ciliary body (Figure 3), Patient 11 (Figure 4) and Patient 12 in the ciliary body, and also in the anterior part of the choroid)). Fibrous membranes were formed at the anterior surface of the iris in 3 cases; in 3 cases there was occlusion of the pupil; and in another case oedema of the ciliary body was found.

\section{CHOROID}

In 3 cases, at the anterior part of the choroid, nonspecific chronic inflammatory cell infiltration was seen. In Patient 12 a small nodule composed of macrophages and a giant cell was seen at the anterior end of the choroid (Figure 5). Other changes seen in the choroid included congestion, oedema, fluid retention in the suprachoroid space, and scar tissue formation. In Patient 2, who showed a local thinning of sclera, the choroid adjacent to the thinned sclera showed atrophy, scar formation and adhesion to the atrophied retina. In 2 cases focal bone formation was noted under the degenerated or fibrosed retinal pigment epithelium layer.

\section{RETINA}

In all eyes, there was atrophy of the retina in various degrees. Mild perivascular small round cell infiltration was noted in some eyes. In Patient 6 small granulomas composed of macrophages, epithelioid cells, lymphocytes, and Langerhans giant cells, with some neutrophils were seen in 1 eye (Figure 6). Retinal detachment was seen in 5 cases and 


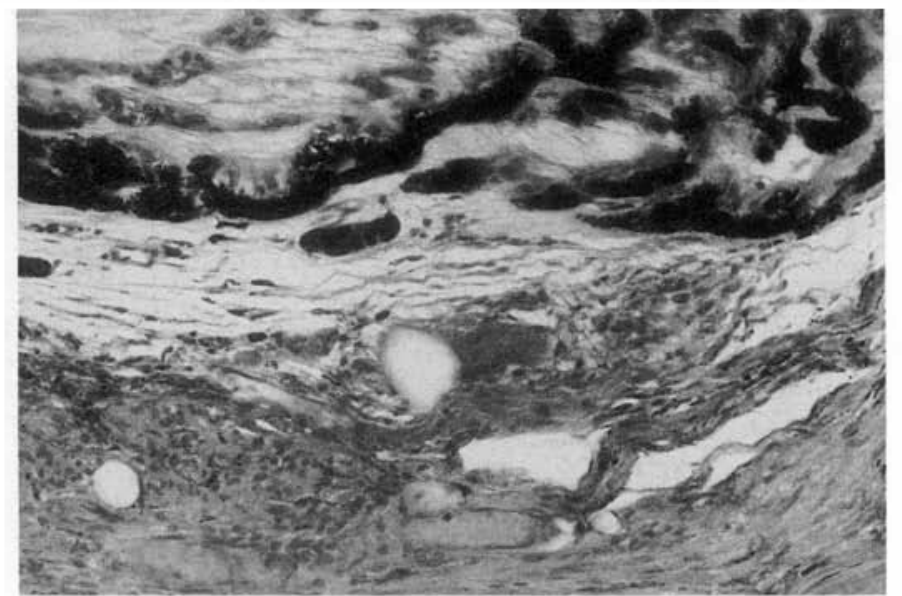

Figure 4. Giant cell and epithelioid cell reactions in the ciliary body (Patient 11). H\&E $\times 400$.

proliferated fibrous tissue protruding from the surface of the retina to the vitreous (retinitis proliferans) was seen in 2 cases, cystic degeneration in 4 eyes and haemorrhage in 1 eye. Destruction and proliferation of the retinal pigment epithelium were noted in many of these eyes.

\section{OPTIC NERVE}

Atrophic changes in various degrees was noted in all the 11 eyes in which optic nerve was found in the slides. Cavernous atrophy (in 1 eye) and cupping of the optic disc (in 3 eyes) were also found.

\section{ANTERIOR CHAMBER}

The anterior chamber angle was obliterated in 11 eyes. The changes in the trabeculae seen

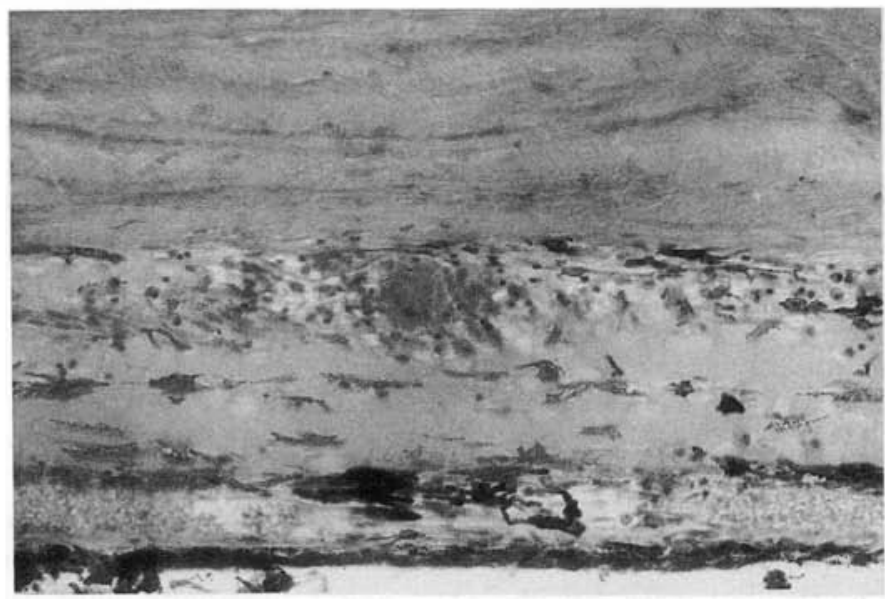

Figure 5. Small tuberculoid reaction in the anterior part of the choroid (Patient 12). H\&E $\times 400$. 


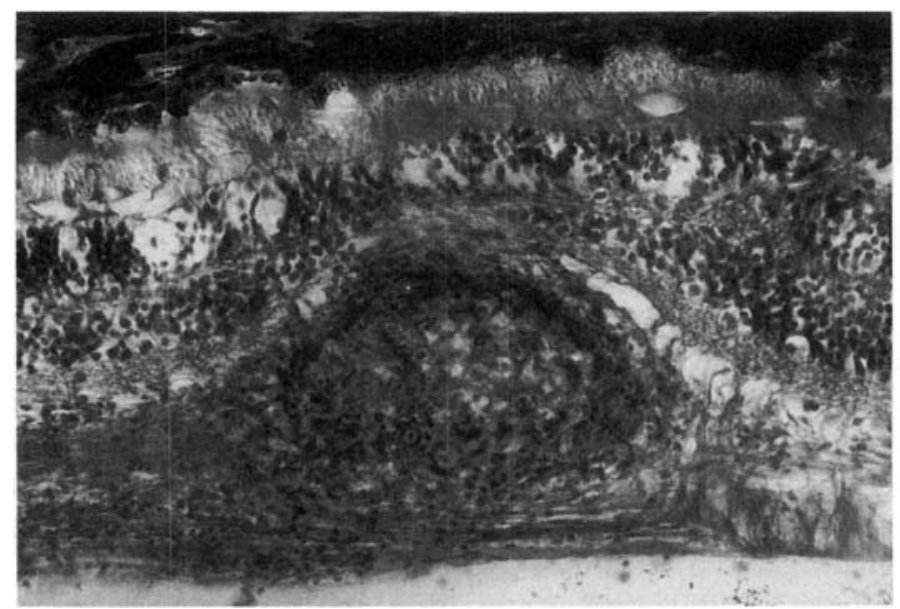

Figure 6. A small granuloma in the inner part of the retina (Patient 6). $H \& E \times 400$.

included homogenization, and fibrosis. In 5 eyes melanin granules were deposited in the trabecular tissue.

\section{LENS}

Cataractous changes were seen in all 10 eyes in which lens could be found in the sections. In Patient 7, the lens capsule was broken and the escaped lens material evoked a reaction with the appearance of foreign body giant cells, macrophages, eosinophils, lymphocytes and plasma cells. Fibrotic tissues were formed around the reacting cells. The proliferated fibrous tissue was stretching and adhering to the iris, ciliary body and the detached retina. In Patient 8, the lens capsule was broken, but no reaction was provoked.

\section{VITREOUS BODY}

In Patients 8 and 9, in the anterior part a cyclitic membrane was formed and in another case blood was dispersed in the vitreous.

In all the slides stained with the Fite-Faraco method, no acid-fast bacilli was found.

The various tissues of 4 cases in which nodules of granuloma were found are summarized in Table 2.

Table 2. The tissues harbor $(+)$ the granulomas in 4 eyes

\begin{tabular}{|c|c|c|c|c|c|c|c|c|c|}
\hline \multicolumn{2}{|c|}{ Patient } & \multicolumn{2}{|c|}{ Disease } & \multicolumn{6}{|c|}{ Tissues } \\
\hline Number & Type & $\begin{array}{l}\text { Duration } \\
\text { (year) }\end{array}$ & $\begin{array}{l}\text { Outcome } \\
\text { of therapy }\end{array}$ & Cornea & Sclera & Iris & $\begin{array}{c}\text { Ciliary } \\
\text { body }\end{array}$ & Choroid & Retina \\
\hline 5 & BT & $*$ & $*$ & + & - & - & - & - & - \\
\hline 6 & LL & $*$ & * & - & + & + & + & - & + \\
\hline 11 & LL & 45 & cured & - & - & - & + & - & - \\
\hline 12 & LL & 32 & cured & + & - & - & + & + & - \\
\hline
\end{tabular}




\section{Discussion}

The lesions in these 12 eyes involved all the intraocular structures showing degeneration and atrophy to various degrees.

Among the lesions seen, the most important were those in the cornea, iris and ciliary body, i.e. in the anterior segment of the eyes.

Nonspecific chronic inflammatory reaction and scar tissue formation were found in the corneas of all the 12 eyes and perforation of the cornea with adhesive leucoma was found in 7. The direct leprosy reactions usually would not cause a corneal perforation. Due to lack of detailed medical histories, we could only suspect that the perforation may be the result of a secondary infection caused by the insensitivity of the cornea and/or the lagophthalmos. The nonspecific inflammatory reaction in the cornea could be a secondary reaction, but the scar formation in the cornea might be the outcome of both a leprosy inflammation and a secondary manifestation.

Chronic nonspecific inflammatory reaction and atrophy in various degrees were found in the iris and ciliary bodies in 11 eyes. This kind of reaction could be the result of leprosy infection and also of intraocular infection secondary to the perforation of the cornea.

Anterior synechia of iris, anterior chamber angle closure secondary to iridocyclitis, scar formation in the trabeculae and pigment deposition in the trabecular region, could all raise the intraocular pressure and be the cause of the atrophy of retina and optic nerve. All the 11 eyes in which optic nerve was seen on their slides showed atrophy of the optic nerve in various degrees. In 3 of them cupping of the disc was noted, and in 1 cavernous degeneration.

The other alterations seen in these eyes, e.g. the nonspecific chronic inflammatory cell infiltration in the choroid and retina, retinitis proliferans, cystic degeneration, oedema, detachment and bone formation in and of the retina, could all be manifestations secondary to iridocyclitis, intraocular hypertension and perforation of the cornea.

The perilenticular ophthalmitis found in 1 eye showing phthisis bulbi was a reaction to the leaked lens material and not related directly to the leprosy infection.

In addition to the nonspecific inflammatory reactions, granulomas composed of macrophages, epithelioid cells, Langerhans giant cells, and lymphocytes, were found in various tissues in 4 eyes. There was no caseating necrosis noted. This kind of tuberculoid granuloma is a lesion found in the segment of the leprosy spectrum higher than the borderline type. The disease in Patient 5 was diagnosed as BT leprosy (without a record of the outcome of this therapy), but those of the other 3 were diagnosed as LL and the outcome of the therapy in 2 of the 3 was noted as cured and that of Patient 6 was not mentioned. Formerly, we had considered that this case might be a borderline leprosy patient, ${ }^{11}$ but the encounter of tuberculoid granulomas in the eyes of 3 of the $5 \mathrm{LL}$ patients made us wonder if there are possible explanations other than to recategorize the patients with this kind of leprosy lesion.

Discrepancy in the histopathological features of lesions in different tissues had been reported. In one report, the authors found in 36 patients the histopathology of their own skin and nerve biopsies differed in 21 , the differences ranging from TT to BL. ${ }^{10}$ Recently, a case with both lepromatous and tuberculoid histology in 1 skin lesion was reported. ${ }^{6}$ There was a report of an autopsy case in which active lesions were found in the eyes while 
the lesions in other tissues showed quiescence or the eye lesions were more active than the others. ${ }^{8}$

In view of these findings, we should consider the possibilities that the clinically 'cured' patients could still harbour tuberculoid inflammatory reactions, and that the manifestation of the tuberculoid granuloma in the eyes of LL patients (even after treatment) might not be rare, and whether an upgrading reaction had occurred in some of the patients. Such tuberculoid relapse as been observed in some patients with lepromatous leprosy, after many years of chemotherapy and bacteriological negativity. ${ }^{12}$

Tuberculosis infection in leprosy patients is not rare. But of eye tuberculosis almost all are haematogenous infections. The distribution of the granulomas in our cases does not seem to agree with that of an infection by this route, and ocular tuberculosis found in 4 cases in 12 randomly-gathered eyes of leprosy patients seems to be too improbable.

No acid-fast bacilli were found in the sections examined. That may effect the true nature but also might be due to the long storage of our specimens (and some were embedded in celloidin). If more sensitive methods to identify the $M$. leprae could be applied to the old slides, we would be glad to search and research them again.

\section{Call for eye specimens}

The findings of this study are clear and have been documented in the figures; however, the interpretation could vary - has to vary, in fact, especially until more material is available for histological examination. Therefore we are searching for eye specimens-either fixed in formalin or already bedded in a paraffin-block or kept in slides-in order to continue the studies. Naturally co-operation of any kind will result in co-authorship, should anything be published in future.

\section{References}

1 Courtright P, Johnson GJ (eds). Prevention of Blindness in Leprosy. London: The International Centre for Eye Health, pp. 25-28, 1988.

2 Bernard JC, Vazquez CAJ. Visceral lesion in lepromatous leprosy, study of 60 necropsies. Int J Lepr, 1973; 41: 94.

3 Brand ME, ffytche TF. Eye complications of leprosy, in Hastings RC (ed): Leprosy, pp. 223-242, Churchill Livingstone, New York, 1985.

${ }_{4}$ Desikan KV, Job CK. A review of postmortem findings in 37 cases of leprosy. Int J Lepr, 1968; 36: 32.

${ }^{5}$ Desikan KV, Job CK. Report on the study of eye lesions in three autopsied cases of leprosy. Ind J Lepr, 1970; 42: $1-4$.

6 Job CK, Jacobson RR, Hastings RC. Intralesional variations from lepromatous to tuberculoid histology-a case report. Int J Lepr, 1991; 59: 116-119.

7 Liu TC, Qiu JS. Histopathological study on peripheral nerves, lymph nodes and visceral organs in various types of leprosy. Ind J Lepr, 1984; 56 (No. 1) Suppl XI/447.

${ }^{8}$ Powell C, Swan L. Pathological changes observed in 50 consecutive necropsies. Am J Path, 1955; 31: 1131 1147.

9 Sakurai H et al. Histopathological findings on 115 corpses of leprosy. Nagashima Arch Lepr, 1964; 6: 17-22. Abs in Int J Lep 1964; 32: 349.

${ }^{10}$ Srinivasan H, Rao KS, Iyer CGS. Discrepancy in the histopathological features of leprosy lesions in the skin and peripheral nerve; report of a preliminary study. Lepr India, 1982; 54: 275-282.

11 Zhou HM, Shi ZR, Job CK. Unusual histological lesions in the eye of a leprosy patient. Int J Le pr, 1987; 55: 507-509.

12 Waters MFR, Ridley DS. Tuberculoid relapse in lepromatous leprosy. Lepr Rev, 1990; 61: 353-365. 


\title{
Une étude histologique des lésions oculaires chez 12 patients lépreux avec lésion tuberculoïde dans 4 yeux
}

\author{
F. Brandt, Z. R. Shi, H. M. Zhou, B. Lu, H. Wu et N. Rai
}

Résumé Nous avons étudié les réactions histologiques dans 12 yeux de 12 lépreux (5 BT, $1 \mathrm{BB}, 1 \mathrm{BL}$ et $5 \mathrm{LL}$ ). Des lésions granulomateuses composées de cellules épitheliales, cellules géantes de Langerhans, macrophages et lymphocytes ont été observées dans divers tissus intra-oculaires, tels que cornée, scléreuse, iris, corps ciliaire ou rétine chez 4 patients (1 BT et $3 \mathrm{LL}$ ). Selon les dossiers, sur les 3 patients LL, 2 ont été guéris, et le résultat du traitement n'a pas été mentionné pour l'autre patient. Étant donné la présence de lésions granulomateuses chez les patients cliniquement guéris, et de granulome tuberculoide dans les tissus intra-oculaires chez les patients LL, existerait-il quelques particularités dans les sites intra-oculaires? ou, peut-être, la réaction tuberculoïde est-elle seulement la manifestation d'une réactivité croissante? Pour répondre à cette question il faudra pratiquer d'autres examens d'yeux dans des cas de lèpre humaine.

\section{Un estudio histológico de las lesiones oculares de 12 pacientes leprosos, con lesiones tuberculoides en 4 ojos}

\author{
F. Brandt, Z. R. Shi, H. M. Zhou, B. Lu, H. Wu y N. Rai
}

Resumen Se estudiaron las reacciones histológicas en 12 ojos de 12 pacientes leprosos (5 BT, $1 \mathrm{BB}, 1 \mathrm{BL}$ y 5 LL). Se encontraron lesiones granulomatosas compuestas de células epitelioides, células gigantes Langerhans, macrofagos y linfocitos en varios tejidos intraoculares, p.e. la córnea, esclerótica, iris, cuerpo ciliar o retina en 4 pacientes (1 BT y $3 \mathrm{LL}$ ). De los 3 pacientes LL, según los registros, 2 fueron curados y no se mencionó el resultado del tercero. En vista del descubrimiento de las lesiones granulomatosas en los pacientes clínicamente curados, y el granuloma tuberculoide en los tejidos intraoculares de los pacientes LL, ¿es posible que hay algo extraño en los sitios intraoculares? ¿O quizás la reacción tuberculoide es solamente una manifestación de una reacción de mejora? Hace falta estudiar más ejemplos de casos oculares en leprosos humanos para poder contestar estas preguntas. 